\title{
Twórczość strajkowa maj - sierpień 1988
}

Anna Błaszkiewicz 


\section{ANNA BŁASZKIEWICZ}

\section{Twórczość strajkowa maj - sierpień 1988}

trajki z maja i sierpnia 1988 niewątpliwie należy uznać za ważny element naszego życia politycznego. Wprawdzie nie bezpośrednio po nich, ale w kilka miesięcy później rozpoczął się przecież nie znany dotychczas proces rozmów politycznych społeczeństwa z władzą. Czy strajki te, ostatnie jak się okazało przed zasadniczą zmianą ustroju, były w jakiś sposób inne od poprzednich?

Zarówno strajki majowe, jak i sierpniowe posiadają bogatą literaturę o charakterze dokumentalnym i analitycznym. Jeszcze w sierpniu 1988 ukazał się w Gdańsku 1. numer „Przeglądu Politycznego”, a w kilka miesięcy później warszawska oficyna „Most” ogłosiła reportaż Wojciecha Giełżyńskiego Gdańsk maj'88. Anatomia strajku przedrukowany potem przez londyński „Aneks”. W rok później w 5 . numerze „Więzi” z 1989 roku ukazało się opracowanie oparte na badaniach.naukowych prowadzonych przez Polskie Towarzystwo Socjologiczne w Gdańsku, Krakowie i Ursusie w 1988 roku, zatytułowane Wiosna Solidarności?, a w roku 1992 "Nowa” wydała książkę Tomasza Tabako Strajk 88 . W opracowaniach tych pojawia się kwestia odmienności pokoleniowej uczestników strajków, rozpatruje się ich znaczeniel społeczne. Marginalnie traktowany jest natomiast ich aspekt kulturowy. Strajki oku ' 88 - podobnie jak i poprzednie z 1970 i 1980 - miały swoistą kulturę. Strajkowy czas zapełniany był piosenkami, występami, zabawą. Część zbiorowych działań kulturowych maja i sierpnia '88 charakterystyczna była dla roku ' 80 . Były to przede wszystkim powtarzalne elementy rytuału religijnego ora:z związana z nimi ornamentyka. W roku 1988 - podobnie jak osiem lat wcześniej modlitwy, spowiedzi, miały za zadanie podtrzymywać strajkujących na duchu. Jednakże potrzeba zewnętrznego manifestowania związku z religią wyraźnie się zmniejszyła. Wprawdzie nadal strajkujący podkreślali wagę zachowań religijnych, lecz sam wystrój stoczni wskazywał na pewne zmiany: krzyże konkurowały ze styropianowymi karykaturami, a kwiaty przed Obrazem Matki Boskiej nie były zmieniane codziennie.

Zmiany dostrzec też można przyglądając się tekstom piosenek, jakie powstały w maju i sierpniu 1988 w Stoczni Gdańskiej. Na początku śpiewano rzeczy stare, głównie Piosenkę o Janku z Gdyni z roku 1970, Mury Jacka Kaczmarskiego, śpiewano je na zmianę $z$ oazowymi. Rychło jednak pojawił się nowy, wyraźnie odmienny repertuar. $W$ tekstach $z$ roku 1988 mamy bowiem do czynienia $z$ inaczej 
określonym niż w roku 1980 bohaterem - podmiotem zbiorowym. To już nie gnębieni robole, jak w roku 1970, i nie świadoma swej siły grupa, postrzegająca siebie jako awangardę społeczeństwa, jak w roku 1980. W piosenkach z roku ' 88 występują ludzie gnębieni, oszukiwani, wiele też mówi się o kłamstwie. Są to piosenki ludzi, którzy w zasadzie nie widzą przed sobą żadnych szans, ale nie mają nic do stracenia, więc buntują się.

Powraca w tekstach majowych i sierpniowych element martyrologiczny, charakterystyczny na przykład dla piosenek z roku 1970: motyw krwi i bólu, ciężaru i kajdan. Są to $w$ dużej mierze figury stylistyczne wielokrotnie wykorzystywane w literaturze rewolucyjnej czy powstańczej. Pojawia się też stara dychotomia: gnębiciele i gnębieni, której towarzyszą obrazy poniewierania robotnikiem, głównie bicie przez milicję. Robotnik zatem to ten, kto jest bity, a za próbę protestu wsadzany do „kryminału”. W jednej z piosenek, Balladzie o stoczniowcu pojawia się nawet ponura wizja grobu młodego stoczniowca, opłakiwanego przez współtowarzyszy. Nutę martyrologiczno-elegijną równoważy jednak chęć walki. Co więcej, okazuje się, że walka jest po prostu koniecznością, jest jedynym wyjściem z sytuacji: „Bo trzeba walczyć o lepszą przyszłość/ Bo trzeba walczyć żeby żyć/ Aby w Polsce żyć godnie i być wolnym."

Rzeczywistość określana jest najczęściej jako „czas niepewności”, okres strajku i walki jakc „czas przebudzenia”. „Czás przebudzenia” nie jest jednak okresem łatwym i radosnym, lecz ciężkim brzemieniem, obowiązkiem, który trzeba wypełnić wobec siebie, swojego pokolenia i wszystkich pracujących. W piosenkach z roku 1988 mniej się jednak mówi - w porównaniu z rokiem 1980 - o Polsce, o społeczeństwie, o zbiorowej misji. Bowiem to już nie misja, ale jedyny ratunek. Dlatego też „za niepodległość, za wolność i za Solidarność”, oddamy to, co mamy: „nasze serca i krew”. Walka o przyszłość to „długa droga”, która musi zakończyć się sukcesem. Prośba do Boga o zwycięstwo - lecz i wiara w nie - pojawia się w większości piosenek. Jeśli zaś nie uda się tym razem, walka tylko się przedłuży: „Wcale jeszcze nie kończymy/ Chociaż dzisiaj tu siedzimy/ Trochę tylko odpoczniemy/ I raz jeszcze spróbujemy".

Inna cechą charakterystyczną piosenek z 1988 roku jest to, że ich twórcami i adresatami są wyraźnie ludzie młodzi, którzy sami chcą stanowić o swoim życiu. Ludzie, którzy ponadto - $i$ to kolejna cecha odróżniająca piosenki gdańskie z roku 1988 od tych z okresu poprzednich strajków - nie boją się skutków bezpośredniej konfrontacji. W tekstach z maja i sierpnia '88 raz tylko mówi się o pertraktacjach z rządem, o negocjacjach czy postulatach. Władza pojawia się w nich rzadko i to w postaci skarykaturowanej, a bezpośrednimi przeciwnikami są milicjanci bądź częściej-zomowcy. W większości piosenki te poświęcone są walkom ulicznym, konkretnym, nierzadko krwawym starciom, a jeśli padają jakieś prośby, to do Boga, aby dał zwycięstwo lub wolę wytrwania, a nie do władz, by poprawiły sytuację w kraju. Bohaterowie ballad strajkowych z roku 1988 zdecydowani są walczyć o lepszą przyszłość i swoje ideały bez względu na konsekwencje.

Ideały, wartości o które się walczy, nie uległy zmianie od lat. To zawsze wolność, prawda, Polska. Wiele się mówi - więcej niż w roku 1980 czy 1970 - o braterstwie i życzliwości w kontaktach międzyludzkich. Jest też kilka piosenek 
poświęconych zdrajcom lub skierowanych do bezpośrednich przeciwników: milicji. Ponad tym wszystkim jednak - jako wartość naczelna - pojawia się Solidarność, traktowana jako żywa legenda. Dlatego w piosenkach strajkowych z roku 1988 słyszymy równocześnie „Chwała i cześć Solidarności” i „Solidarność zwycięży znów".

Poniżej prezentujemy zbiór piosenek śpiewanych w Stoczni Gdańskiej w maju i sierpniu '88 roku. Twórcą prawie wszystkich (zarówno słów jak i melodii) jest Zbigniew Stefański, (rocznik 1960.), uczestniczący od samego początku w majowej, a potem sierpniowej akcji protestacyjnej.

Teksty zostały zebrane w sierpniu i listopadzie 1988 roku przez autorkę tych słów. Niezależnie część piosenek strajkowych ukazała się w 1 . numerze „Przeglądu Politycznego".

W komentarzu wykorzystane zostały fragmenty własne tekstu napisanego wspólnie ze Zbigniewem W. Rykowskim, Piotrem Szwajcerem i Jerzym Wertensteinem-Żuławskim Wiosna Solidarności?, „Więź” maj 1989 r.

GDY PRZYSZEDL MAJ

(melodia własna)

Gdy przyszedł maj stanęła stocznia,

Gdy przyszedł maj zawrzała krew.

Ktoś krzyknął nam: „Chodźcie na bramy,

Nie bójcie się, bo cały lud jest z nami."

Solidarność zwycięży znów! (4 razy)

Pod bramy przyszły żony i matki

By nas pokrzepić i dodać sił

„Nie martwcie się, jesteśmy z wami!"

My zwyciężymy, to łatwiej będzie żyć!

Solidarność zwycięży znów! (4 razy)

Już dołączyli do nas Portowcy

Już dalsze stocznie zaczęły strajk

Partia nas straszy! Lecz zwyciężymy

Bo przecież czeka na to cały świat! (kraj)

Solidarność zwycięży znów! (4 razy) 
NIE WYJDZIEMY ZE STOCZNI...

Pada deszcz majowy, pada deszcz

Wokół nas tyle milicji jest

A my tu siedzimy trzeci dzień

Strajk nasz trwa i nic nie zmienia się

refren: $\quad$ Nie wrócimy do domów

Póki sił nam wystarczy

Nie wyjdziemy ze stoczni, o nie

Załatwimy tę sprawę, o którą walczymy

Czy nam tu będzie dobrze, czy źle

Wielu już dzisiaj opuściło nas

Ale my będziemy tutaj trwać, wiecznie trwać

Może wnet nadejdzie lepszy czas

Aby nam podwyższyć stawki płac.

refren: Nie wrócimy do domów...

\section{WSPANIALI CHŁOPCY}

W poniedziałek rano strajk zaczęli.

Chociaż było ich niewielu, Jednak bardzo się zawzięli

I zdążają znów do celu

refren: A nasi stoczniowcy wspaniałe chłopaki

Wcale się nie boją z Zomowcami draki.

Rzecznik Urban' nas szkaluje

Wszystkich wokół okłamuje.

Nie zda mu się ta poruta

Przecież z nami Nowa Huta²

refren: $\quad$ A nasi stoczniowcy...

1 Jerzy Urban - rzecznik prasowy rządu.

${ }^{2}$ Były trzy ogniska strajkowe: Gdańsk, Nowa Huta i Ursus. 
Tam pod stocznią ZOMO stoi

Stoi i się bardzo wścieka

Bo stoczniowcy znów strajkują

A komunę klęska czeka.

refren: $\quad$ A nasi stoczniowcy...

Wszystko wokół okrążyli

Oderwali nas od świata

A my i tak zwyciężymy

Na nic cała ta blokada.

refren: A nasi stoczniowcy wspaniałe chłopaki

Wcale się nie boją z Niebieskimi draki

(inna wersja refrenu, stosowana przemiennie)

Dostał Deptała ${ }^{3}$ zadanie

W stoczni zrobić rozpoznanie (Zrobić w stoczni rozpoznanie)

Nawet ciecie $z$ demobilu

Krążą w stoczni po cywilu.

refren: $\quad$ A nasi stoczniowcy...

A Tołwiński ciągle straszy

Jednak my się nie boimy

Dociagniemy to do końca

I tak w sierpniu zwyciężymy

refren: $\quad$ A nasi stoczniowcy...

Andrzejewski ${ }^{5}$ wraz z Kiszczakiem ${ }^{6}$

Oba cudze generały

Kombinują w dzień i w nocy

Dla swojej czerwonej chwały

refren: $\quad$ A nasi stoczniowcy...

${ }_{3}^{3}$ Tadeusz Deptała - dyrektor ds. technicznych Stoczni Gdańskiej. 7 maja 1988 roku o godzinie $8^{15}$ kilkudziesięciu pracowników dozoru zmobilizowanych do stoczniowej służby porząadkowej, dowodzonych przez dyr. Tadeusza Deptałę usiłowało przedostać się do stoczni. W tym samym momencie na czele 200-osobowej pikiety wezwanej przez straż strajkową przybył Lech Wałęsa. Tak zawiązał się quasi-wiec.

${ }^{4}$ Czesław Tołwiński - dyrektor naczelny Stoczni Gdańskiej im. Lenina.

${ }_{5}^{5}$ Jerzy Andrzejewski - generał MO, szef wojewódzkiego Urzędu Spraw Wewnętrznych w Gdańsku.

${ }^{6}$ Czesław Kiszczak - generał, minister spraw wewnętrznych. 
Ponad tydzień wszystko trwało W całym świecie bardzo wrzało Choć niełatwo się nam żyło Wszystko dobrze się skończyło.

refren: $\quad$ A nasi stoczniowcy...

Wcale jeszcze nie kończymy

Chociaż tutaj dziś siedzimy

Trochę tylko odpoczniemy

I raz jeszcze spróbujemy.

refren: $\quad$ A nasi stoczniowcy...

śpiewane tylko niektóre zwrotki.

Raz na lekcji Michał płakał Pani pyta co się stało Michał nic nie odpowiadał

Ciągle placząc i szlochając (dwa ostatnie wersy w każdej zwrotce powtarzane)

Pani prosi, pani pyta

Co się chłopcze tobie stało

Kto cię skrzywdził czy uderzył

Jakie nieszczęście cię spotkało.

Nikt mnie nie zbił, mówi chłopiec

Coś gorszego się zdarzyło

Przyszli w nocy, wzięli tatę

Nie wiem, o co im chodziło

Wciąż krzyczeli na tatusia

Aby szybko się ubierał

Siostra stała i płakała

Mamie serce ból rozdzierał 
Ach panowie, co robicie

Woła w progu jeszcze mama

Czy wy tego nie widzicie

$\mathrm{Z}$ dwojgiem dzieci będę sama.

Oni tylko się zaśmiali

Ciągle drwiąc z mojej mamy

Tatę bili i kopali

A los jego jest nieznany.

Gdy go pani pocieszała

Jeszcze tego nie wiedziała,

Że los tego robotnika

W swoje ręce wzięła klika.

\section{SMERFY ${ }^{7}$}

(na ludową melodię Hej, bystra woda)

Hej, bystra woda, bystra wodiczka

Pytało dziewczę o Janicka

Hej, lesie ciemny, wierchu zielony

Kaj mój (to) Janicek umilony?

Hej, bystra woda, kaj wielka piana

Pytają ludzie o Urbana

Hej, lesie ciemny, wierchu zielony

Kaj to nasz Jerzyk ${ }^{8}$ umilony?

Hej, powiadali, hej powiadali

Hej, co Urbana porubali

Hej, porubali go robotniki

Hej, za kłamliwe jego krzyki

Hej, w telewizji nastąpi zmiana

Hej, nie zobaczym już Urbana

Hej, póki co my tutaj będziemy

Jaka jest prawda pokażemy!

Będziem w sobotę, będziem w niedzielę

Niech stąd smerfują Gargamele ${ }^{9}$

${ }^{7}$ Smerfami nazywali stoczniowcy milicję; bajkowe skrzaty z animowanego filmu dia dzieci wyświetlanego na dobranoc i bardzo popularnego były niebieskie.

${ }^{8}$ Oczywiście chodzi o Jerzego Urbana.

${ }^{9}$ Gargamel - „czarny charakter” z bajki o smerfach. Gargamelami nazywali strajkujący członków rządu. 
Niech stąd smerfują, niech uciekają

A w piekle już na nich czekaja

Grzeje się wrzątek, bulgoce smoła

Smażą się Smerfy dookoła

Niebieski kolor odparowuje

Czerwony bardziej im pasuje!

W Polsce jest ZOMO, jest smerfów wiele

A wszystkim rządzą Gargamele

Główny z nich Wojciech ${ }^{10}$ bardzo się stara

By nie cierpiała Smerfów wiara

Chce by się ludzie nie rozumieli

Naród się rozbił i podzielił

Widzicie państwo to tak jak w bajce

Dobrze się żyje onej szajce

My nie pozwólmy, by taka klika

Dalej grabiła robotnika!

Ci co chcą bronić tego ustroju

Niech biorą widły i do gnoju!

Niech wszyscy biorą i niech machają

Do tego tylko się nadają.

My będziem prosić i pertraktować

Jak nie pomoże, znowu strajkować

Nie chcemy władzy, chcemy wolności

Chwała i cześć „Solidarności”!!! (powtórzenie dwóch ostatnich wersów)

NIE CHCEMY KOMUNY

(na melodię Ta szara piechota)

Nie chcemy komuny, nie chcemy i już

Nie chcemy ni sierpa, ni młota

Za Katyń, za Grodno, za Wilno i Lwów

Zapłaci czerwona hołota

(powtórzenie dwóch ostatnich wersów w każdej zwrotce)

${ }^{10}$ Ówczesny przewodniczący Rady Państwa i pierwszy sekretarz PZPR, Wojciech Jaruzelski. 
Za gwalty, morderstwa, cierpienia i łzy

Za lata w niewoli spędzone

Za fałsze, oszczerstwa i cyniczne gry

Nadzieje bestialsko zniszczone.

Od Jatty ten koszmar sowiecki już trwa I z każdym wciąż rokiem narasta.

Nie lękaj się walki, w szeregu dziś stań Przed tobą czerwona hałastra.

Nie chcemy komuny, podnieśmy swój głos Nasz protest do Kremla już dotarł Uchwyćmy w swe ręce parszywy nasz los

Niech płaci czerwona hołota

Choć w celach ponurych, nadzieja w nas tkwi Wolności uchylą się wrota.

Nadeszły dla WRONY ${ }^{11}$ ostatnie już dni Zawiśnie czerwona hołota.

Nie chcemy komuny, nie chcemy i już!!!

\section{BALLADA O STOCZNIOWCU}

Oczy miał niebieskie, włosy jasnoblond

Ach powiedz dziewczyno, ach powiedz jak i skąd?

Pamiętam, że na strajku, tam poznaliście się

A twoje młode serce do niego aż się rwie.

refren: A zimny, a zimny, a zimny wicher dmie

A grupa stoczniowców na bramy aż się rwie

Ach wiwat dziewczęta, dziewczęta głośny śpiew

My młodzi stoczniowcy, co rozpalamy krew

(w refrenie powtórzenie dwóch ostatnich wersów)

Widziałem na ulicy, milicjant bił go w twarz

Ach powiedz stoczniowcu, gdzie ty ulotki masz.

I krew mu zalała uczciwa jego twarz

I umarł stoczniowiec jak polskiej róży kwiat

refren: A zimny, a zimny...

"WRON - Wojskowa Rada Ocalenia Narodowego powołana przez Wojciecha Jaruzelskiego 12 grudnia $1981 \mathrm{r}$. 
Pogrzeb miał piękny, tak piękny niczym ślub

Gdy grupa stoczniowców kopała jego grób

A gdy go puścili do grobu ciemnego

To zapłakali rzewnie nad zwłokami jego.

refren: A zimny, a zimny...

Widziałem, widziałem, widziałem

Jak stoczniowiec padał od kuli

Widziałem, widziałem, widziałem

Jak drugiego w kajdany zakuli

Widziałem, widziałem, widziałem

Splamione krwią robotników sztandary

Widziałem, widziałem, widziałem

Jak nasze matki płakały

refren: $\quad$ Zapamiętaj mój synu kochany

Ten obraz tak okrutny, lecz znany

Pamiętaj mój synu kochany

Ten obraz tak okrutny, lecz znany

(na tę samą melodię co refren)

Pamiętaj też synku najdroższy

że twojego tatusia pobili

A przecież syneczku kochany

Myśmy tylko chleba prosili

Widziałeś synku jak bardzo

Wrócilem z pracy pobity

Zapamiętaj mój synku kochany

To zrobili czerwoni bandyci.

refren (nadal ta sama melodia): Zapamiętaj mój synu kochany...

\section{MODLITWA}

Ty wiesz jak nam jest ciężko

Ty wiesz czego nam brak

A więc Boże daj nam zwycięstwo

$A$ więc Boże pozwól wygrać nam

(w każdej zwrotce powtórzenie dwóch ostatnich wersów) 
Codziennie szukamy łaski Twojej

Która nadzieję daje nam

że okażesz Swoją miłość

że uchylisz niebios bram

Na razie, Drogi Panie Boże

Musimy brzemiona nasze nieść

Lecz słowo Twoje w sercach naszych

Pomaga wszelkie trudy znieść.

Gdy przyjdzie wreszcie dzień zwycięstwa

Tobie, Boże hołd oddamy

Bo nas broniłeś w chwilach ciężkich

Bo jesteś Boże zawsze z nami.

Ty wiesz jak nam jest ciężko

Ty wiesz czego nam brak

A więc Boże daj nam zwycięstwo

A więc Boże pozwól wygrać nam.

(w powtórzeniu „daj nam dziś zwycięstwo")

MARIO, MATKO POLSKIEJ ZIEMI

Mario, Matko Polskiej Ziemi

I nadziejo wszystkich nas

Twą nadzieją dziś żyjemy

W złej godzinie obroń nas.

Ty co brałaś nas w obronę

Nie opuszczaj Matko nas

Wspomóż ludzi umęczonych

W złej godzinie obroń nas!

Ciebie Matko miłujemy

Od Battyku aż do Tatr

Z Tobą, Matko strajkujemy

W złej godzinie obroń nas! 
PIOSENKI PÓŹNIEJSZE, zebrane w listopadzie $1988 \mathrm{r}$.

(na melodię Było morze)

Był se kraik

W Europie

W tym kraiku

Każde chłopię

Gdy je spytasz

Na ulicy

Kto tu rządzi

To odpowie:

Bolszewicy

Powiedz chłopcze

Kto bolszewik

Kto mój tata

Moja mama

Wszyscy oni

Mają władzę

Jak to powiem

To niewiele

Tu przesadze

Było miasto

W mieście pomnik

Ktoś znajomy

$W$ marynarce

Ten naczelnik

To wódz wielkiej Rewolucji

Włodzio Lenin

Tu symbole

Tam podiumy

Tu idole

Tam kostiumy

Naród w ryzach

$\mathrm{UB}^{12}$ trzyma

Żadna zima

Się dlatego nas nie ima

${ }_{12}$ UB - Urząd Bezpieczeństwa (Publicznego). Instytucja istniejąca w latach 1944-1954. Nazwa używana w zastępstwie skrótu MSW lub SB. 
Ludzie głodni

Cicho stoją

Nieporadne

Miny stroją

Jak tu myśleć o oporze

Kiedy wokół wielkie

Socjalizmu morze.

Było morze

$W$ morzu stołek

$Z$ tego stołka

Spadł Kociołek ${ }^{13}$

$\mathrm{Na}$ tym stołku

Zaś generat'14

Wobec Loni ${ }^{15}$

Bezwstydnie się rozpierał

Kiedy całkiem

Się odsłoni

Odda wszystko

Tacie Loni

W zamian za to

Wielki Brat

Republiką nas uczyni

Kraju Zdrad.

W niepewności

Czas się kończy

Każdy będzie

Miał swój kącik (za kratkami)

Dużo pracy

Bez pieniędzy

morat: Bo komunizm to jest równy podział nędzy.

${ }^{13}$ Stanisław Kociołek - w grudniu 1970 r. wicepremier rządu, zdjęty z tego stanowiska po strajkach stoczniowców.

${ }^{14}$ Choć nie ma związku logicznego z poprzednimi wersami, prawdopodobnie chodzi o Wojciecha Jaruzelskiego.

${ }^{15}$ Chodzi o Leonida Breżniewa, ówczesnego przywódcę Związku Radzieckiego. 
Dlaczego mówicie, że chcecie nam pomóc

Dlaczego to kłamstwo wciąż wraca

Przecież wami rządzi nienawiść

A naszym celem jest praca

refren: Dlatego przestańcie nas okłamywać

Jak wam na Polsce zależy

Przecież już dawno kraj sprzedaliście

I nikt wam już nie uwierzy (powtórzenie całego refrenu)

Ludzie na bruk wyrzucani

Żądają chleba i pracy

Jak możecie patrzeć im w oczy

Przecież to wasi rodacy

refren: Dlatego przestańcie nam opowiadać

Jak wam na Polsce zależy (zmiana pierwszego wersu)

Gdy prosty robotnik o swoje prawa

Się upominał

Wyście kajdany mu założyli

Poznał co to kryminat

refren: Dlatego przestańcie nam opowiadać...

Jedna już

padła ofiara skrwawiona

Od kuli czerwonego brata

Mówicie do nas o miłości

A zatrudniacie kata.

Refren: Dlatego przestańcie nas okłamywać... 
HYMN DYMU $^{16}$

Po ulicach naszej stoczni znów radiola mknie

Oo, znów radiola mknie, oo, znów radiola mknie

Zaraz zacznie, zaraz zacznie zamykanie się, zamykanie się

(wersja II zaraz zaczną napierdalać się)

Oo, zamykanie się, zamykanie się

Ale my łatwo glinom nie poddamy się, nie poddamy się

Bo nam, serce się do walki rwie, serce rwie, serce rwie.

refren: $\quad 000$ stocznia Gdańsk, stocznia Gdańsk

000 (narastająco)

\title{
NÓWKA
}

Gdy dupną ciebie chłopcy

Chłopcy z MSW ${ }^{17}$

Poczujesz drogi bracie

Na dupie swojej ból

Powiodą cię pod celę

Sypną parę pał

Abyś o milicji

Dobre zdanie miał

refren powtarzany dwukrotnie: na melodię dziecinnej piosenki:

\author{
Uśmiechnij pięknie się \\ Podziękuj pięknie im \\ Przecież dobrze wiesz \\ Kto tu wiedzie prym.
}

\footnotetext{
${ }^{16} 1$ września 1988 roku o godzinie 8 rano na wiecu przy drugiej bramie Stoczni Gdańskiej odczytano oświadczenie Międzyzakładowego Komitetu Strajkowego kończące strajk. Potem przemawiał Wałęsa. Grupa młodych (podówczas mieli oni po dwadzieścia kilka lat) stoczniowców nie pozostała do końca uroczystości, czyli do godziny 14 . W południe opuścili stocznię uczestniczący cały czas w strajku: Zbigniew Stefański (stoczniowy bard), Paweł Świerczyński, Gerhard Kreinbring i Sławek Adamski. Porozumienie uznali za zdradę. Na popołudniowej „stypie strajkowej” postanowili „walczyć dalej z komuna”. Tak powstała organizacja „Dym ”, której nazwa wzięła się od popularnej „zadymy”, jakim to mianem określano potyczki z milicją i ZOMO.

„Dym” nie funkcjonował długo. Jego założyciele nie potrafili związać ze swoją organizacją młodych ludzi. Rozeszły się też drogi strajkowych przyjaciół. Sławek wyjechał na Mazowsze, do rodzinnego Tomaszowa, Paweł wyjechał z kraju. Zbyszek włączył się do ruchów ekologicznych, Gerhard natomiast nie umiał już na powrót wdrożyć się do normalnego życia i pracy.

${ }^{17}$ Ministerstwo Spraw Wewnętrznych.
} 
Gdy na przesłuchaniu

W mordę będą lać

Widząc tych pajaców,

Będziesz się z nich śmiać

Jeden kopnie w oko,

Drugi trafi w nery

Przecież demokracja

$U$ nas do cholery.

refren: Uśmiechnij pięknie się...

Czemu ekstremisto

Nic nam tu nie mówisz

Przecież już za chwilę

Wszystkie zęby zgubisz

Słowa popieraja

Biciem i kopaniem

Nawet ta metoda

Ekstremy nie złamie

refren: $\quad$ Uśmiechnij pięknie się...

$\mathrm{Na}$ to ty z uśmiechem

Grzecznie odpowiadasz

Wolę starcić zęby

Niż z durniami gadać

Na tym całe śledztwo

Zostało skończone

Gliny nic nie wiedzą,

My robimy swoje.

refren: $\quad$ Uśmiechnij pięknie się...

Chłopcy uwierzcie, przed wami długa droga.

Chłopcy powstańcie, pora iść

Bo trzeba walczyć o lepszą przyszłość

Bo trzeba walczyć aby żyć. 
refren powtarzany 4 razy:

Aby w Polsce żyć godnie

I być wolnym

Długo mówiono, że jest nam tu dobrze

Długo to kłamstwo żyło w nas

Aż wreszcie przyszedł czas przebudzenia

I dzisiaj wszystko woła w nas

refren: $\quad$ Aby w Polsce żyć godnie

I być wolnym.

\title{
MANIFA
}

(piosenka dla Joanny ${ }^{18}$ )

tekst mówiony:

Gdy wyszliśmy na ulicę, aby powiedzieć jak nam ciężko

Wy staliście naprzeciw z pałami

Padł rozkaz: bij i znów krew polała się strumieniami

spiewane:

Wy nie widzicie jak nam ciężko

Wy nie widzicie bólu i łez

Dla was robotnik nie jest człowiekiem

Dla was robotnik to podły pies (dwa ostatnie wersy powtarzane)

\author{
Jesteście młodzi \\ Przed wami życie \\ Jesteście młodzi i bardzo źli \\ Nie wasze matki \\ Ani wasz ojciec \\ Lecz tylko przemoc \\ Wam się śni (cztery ostatnie wersy powtarzane)
}

18 Joanna Wojciechowicz była stałym informatorem rozgłośni Wolna Europa, i również najlepsza przyjaciółką i opiekunką młodych strajkujących. Jej gdańskie mieszkanie było punktem kontaktowym, ale $w$ razie potrzeby noclegownią zarówno dla uciekających przed milicją, jak i po prostu dla zbłąkanych dusz. 
Wy macie pały

Niebieski mur

My mamy serca

I polską krew

Którą oddamy za „Solidarność"

Którą oddamy, gdy zabrzmi zew

Którą oddamy za niepodległość

Którą oddamy gdy zabrzmi zew.

\section{DOPÓKI}

mówione:

Gdy usłyszysz słowa tej piosenki, pomyśl, że wielu ludziom jest ciężko, lecz ty możesz to zmienić, przynieść wolność i zwycięstwo.

śpiewane:

Dopóki kłamstwo wokół jest Dopóki ludziom krzywdzi się Ty solidarnie bracie stój I walcz o dzisiejszy dzień (dwa ostatnie wersy powtórzone)

Niech zamilknie kobiet płacz

I niech każdy w nocy śpi

Będąc spokojnym, że rano nikt

Nie będzie wyważał jego drzwi (dwa ostatnie wersy powtarzane)

Na razie niepewności czas

Spędza ludziom z oczu sen

Bo jak spokojnie w nocy spać

Gdy niepewne jutro jest (dwa ostatnie wersy powtórzone)

Ludzie do pracy garną się

Aby dzieciakom dać coś zjeść

Lecz jak pracować można gdy

Z oczu płyną gorzkie łzy (dwa ostatnie wersy powtórzone)

Dopóki kłamstwo jest

Dopóki ludzi bije się

Ty solidarnie bracie staj

I walcz o dzisiejszy dzień (dwa ostatnie wersy powtórzone) 